短 報 $[$ Note]

\title{
琵琶湖南湖の沈水植物の分布拡大はカタストロフィックシフトで 説明可能か?
}

芳賀裕樹 $^{1)} \cdot$ 大塚泰介 $^{1)}$

\section{Can the catastrophic-shift model explain the sudden expansion in the distribution range of submerged macrophytes in the southern basin of Lake Biwa?}

\author{
Hiroki HAGA and Taisuke OHTSUKA
}

\begin{abstract}
We evaluated whether or not the distribution range of submerged macrophytes in the southern basin of Lake Biwa between 1979 and 2004 had been restricted by light conditions on the lake bottom. The potential vegetated area (i.e., the area where submerged macrophytes might be expected to occur judging from the light conditions) was estimated using the data of transparency and water levels periodically measured by the Shiga Prefectural Government and the Ministry of Land, Infrastructure and Transport of Japan. Throughout this period, the potential vegetated area was mostly determined by the transparency together with a slight additional influence of variations in the water level. The evaluated vegetated area ranged $9-48 \%$ of the potential vegetated area from 1979 through 1994. The extreme drawdown to $-1.23 \mathrm{~m}$ of the standard Biwako Surface Level (B.S.L.) in September, 1994, did not induce an expansion of the potential vegetated area, which was rather due to a simultaneous decrease in transparency. The potential vegetated area in August, September, and October, 1994, was not significantly more extensive than that in same period in preceding years. Therefore, we are persuaded that light conditions on the lake bottom were not the sole factor regulating the distributional range of submerged macrophytes in the southern basin of Lake Biwa from 1979 to 1994. Based on these results, we concluded that the catastrophic-shift model requires light limitation does not furnish an appropriate rationale to explain mechanisms of a sudden expansion of submerged macrophytes in the southern basin of Lake Biwa.
\end{abstract}

Key words: submerged macrophytes, distribution, environmental factor, light, southern basin of Lake Biwa

\begin{abstract}
摘 要
湖底の光環境が 1979 年から 2004 年の琵琶湖南湖の沈水植物の分布範囲を制限する要因となっていた かどうかを検討した。滋賀県と国土交通省が行っている定期観測の透明度と水位のデータを用いて南湖 に設定した 200 地点で沈水植物の分布の可否を推定した。全期間を通じて，沈水植物が分布可能な水域 の面積は透明度でほとんど規定され，水位の影響は小さかった。観測された沈水植物の分布範囲の面積 は, 1979 年から 1994 年までは潜在的な分布範囲の面積の 9 〜 48\% に過ぎなかった。1994 年 9 月におこっ た琵琶湖基準水位 $-1.23 \mathrm{~m}$ に達する極端な水位低下は，同じ時期に透明度が低下したために沈水植物の 分布可能な範囲の拡大をもたらさなかった。また，1994 年の 8, 9, 10 月の沈水植物の分布可能な範囲 の面積は，1979～1993 年のそれらに較べて特に広くなかった。以上の結果から，1979〜1994 年の南湖
\end{abstract}

\footnotetext{
1) 滋賀県立琵琶湖博物館 $\mathbf{T} 525-0001$ 滋賀県草津市下物町 1091 番地Ｌake Biwa Museum, Oroshimo-cho 1091, Kusatsu, Shiga 525-0001, Japan
} 
の沈水植物の分布範囲を制限していたのは湖底の光環境だけではないと考えられた。したがって近年の 南湖の沈水植物の分布拡大は, 光制限の存在を基盤とするカタストロフィックシフトでは説明できない という結論を得た。

キーワード：沈水植物, 分布, 環境要因, 光, 琵琶湖南湖

(2007 年 2 月 18 日受付； 2008 年 7 月 4 日受理)

\section{はじめに}

日本の多くの湖では富栄養化や湖岸の改変によって 沈水植物が衰退または消滅している（Takamura et al., 2003)。琵琶湖南湖でも沈水植物の分布面積が 1930 $\sim 50$ 年代の $23 \sim 27 \mathrm{~km}^{2}$ から 1964 年の $0.6 \mathrm{~km}^{2}$ に縮小 し，1994 年に至るまで $6 \mathrm{~km}^{2}$ 未満で推移した（芳賀 ら，2006）。しかし最近では, 沈水植物の分布範囲は拡 大に転じ，2000 年には 29 $\mathrm{km}^{2}$ (Hamabata and Kobayashi, 2002), 2002 年には南湖の全水面面積の $83 \%$ に相当す る $43 \mathrm{~km}^{2}$ に達した（芳賀ら，2006）。南湖の沈水植物の 回復は生態学上貴重な例と言えよう。一方で沈水植物の 急激な拡大は漁業被害や航行障害, 景観悪化などの社 会問題も引き起こしている（大塚ら，2004）。このため, 生態学的にも社会的にも, 南湖の沈水植物の分布拡大の 原因解明が課題となっている。

沈水植物の分布が急に拡大に転じた原因や，分布拡 大が続いた原因について, 浜端 (2005) は Scheffer et al. （2001）のカタストロフィックシフトモデルを適用して 次のように説明した。1994 年以前の南湖は植物プラン クトンが優占する濁った状態（turbid state; Scheffer et al. 2001）だった。ところが，1994 年 9 月に琵琶湖基準水 位（B.S.L）-1.23m に達する水位低下があり，一時的 に湖底の光環境が向上したのを契機として, 沈水植物が 優占する透明な状態 (clear state; Scheffer et al. 2001) に 移行した。1994 年以降は沈水植物の分布拡大に伴う透明 度の上昇が，分布範囲の拡大を維持している。

前述の説明は非常に明快である。しかしながら, Scheffer et al. (2001)のモデルは栄養塩濃度と濁度のみ を変数とする非常に単純な系であり, 実際の湖沼の現 象を説明できるかどうかは慎重に検討しなければならな い。特に turbid state から clear state 一の移行を述べるた めには, 1994 年以前の南湖の沈水植物の分布が光によ る制限を受けていたことを証明する必要がある。しかし， 浜端（2005）やその報告の基礎となった Hamabata and Kobayashi (2002) では, 湖底の光条件に関する検証は行
われていない。

南湖の湖底の光環境を直接観測したデータは見当たら ない。しかし, 滋賀県と国土交通省が毎月行っている定 期観測の透明度のデータと, 国土交通省が毎日観測して いる水位のデータから, 沈水植物が分布可能な範囲を推 定するモデルが，大塚ら（2004）および芳賀ら（2006） によって提唱されている。そこで本研究では, 大塚ら （2004）- 芳賀ら（2006）のモデルを用いて，1979 年か ら 2004 年の南湖の沈水植物の分布可能な範囲の推定を 行い, 実測された分布範囲との対応について検討した。 また, 1994 年の水位低下が沈水植物の分布拡大の原因 となった可能性についても検討した。これらの検証結 果に基づき, 南湖の沈水植物の分布拡大がカタストロ フィックシフトモデルで説明できるかどうかを考察し た。

\section{方法}

\section{推定に使用したデータ}

透明度のデータとして, 滋賀県と国土交通省が行って いる琵琶湖の定期観測の值を滋賀県環境白書資料編（滋 賀県，1980-2005）から得た。入手したデータの期間は 毎月の観測が始まった 1979 年から最新の 2004 年までで ある。現在, 南湖では 20 地点で定期観測が行われてい るが，1991 年までは「新杉江港沖」を除く 19 地点で観 測が行われていた。また 1979 年と 1980 年は矢橋人工島 の建設に伴い「浜大津沖中央（旧名 浜大津一十禅寺 川沖中央）が欠測となっており，この時の観測地点数は 18 だった。

水位のデータは国土交通省の琵琶湖水位のデータを使 用した。2001 年 3 月までのデータは一括して滋賀県河 港課より提供を受け, それ以降のデータは国土交通省琵 琶湖河川事務所が公開している水位の日観測データから 入手した。琵琶湖水位は 1991 年までは鳥居川観測地点 の值が，それ以降は鳥居川を含む琵琶湖 5 地点の平均値 が発表されている。 
透明度の観測地点数の変化と琵琶湖水位の算出方法の 違いが沈水植物の分布範囲の推定に与える影響の検討方 法は，次項で述べる。

\section{沈水植物が分布可能な水域の推定}

潜在的に沈水植物が分布可能な光条件の水域（以下， 潜在植生水域と記す）の推定には大塚ら（2004）のモデ ルを用いた。このモデルでは透明度に補償深度／透明 度比を乗じ，水位を差し引いた值を有光深度とよび，琵 琶湖基準水位（B.S.L.）時のその地点の水深より有光深 度が大きい場合に沈水植物が分布可能と判断する。沈水 植物の分布の可否の判定は南湖に 500m メッシュで設け た格子点 195 地点で行うが，手順としてはまず滋賀県と 国土交通省の定期観測が行われている 20 地点について 有光深度を計算し, さらに $\sigma=1 \mathrm{~km}$ の正規分布フィルタ を用いた重文付け平均を用いて各格子点の有光深度を求 め, 各地点の水深と比較を行う。なお, 大塚ら (2004) は 20 地点の透明度から 195 地点の透明度を推定し, 地 点ごとに有光深度を計算したと報告したが，その記述は 誤りだったので，ここで上記の手順に修正する。結果に ついては既報のまま変更はない。大塚ら（2004）は沈水 植物が分布可能となる光条件として, 有光深度が水深を 上回る期間が $2 \sim 3$ 个月必要と仮定し, 有光深度の上位 3 番目の值を用い，その上で補償深度／透明度比が 2.0 のときに推定された分布範囲と実測された分布範囲がよ く一致することを示した。芳賀ら（2006）は同じモデル を 2002 年の分布調査の結果に適用した場合, 実際の分 布範囲が推定された分布範囲より大きくなることを見出 し，有効深度の条件を上位 3 番目から 2 番目に緩和する 必要があると指摘した。これらの報告を踏まえ，本研究 では補償深度／透明度比を 2.0 , 有効深度の境界条件を 上位 2 番目として, 沈水植物の分布範囲の推定を行った。 大塚ら（2004）は琵琶湖大橋を北端，近江大橋を南端と する 195 地点沈水植物の分布の可否を推定した。本研究 ではこれに近江大橋以南，JR 鉄橋までの水域の 5 地点 を加えた 200 地点の推定を行った (Fig. 1)。

大塚ら（2004）の作成したモデルでは南湖 20 地点の 透明度と水位から潜在植生水域を推定するが，透明度の 観測は $1981 〜 1991$ 年が 19 地点, $1979 \sim 1980$ 年が 18 地点しか行われていない。大塚ら（2004）のモデルはそ らした欠測值を扱うことができないため,大塚ら（2004） のモデルを改変し、「新杉江港沖」および「浜大津沖中央」 に関する項を適宜消去して 19 地点または 18 地点の透明 度から潜在植生水域を推定するモデルを別に作成し，結

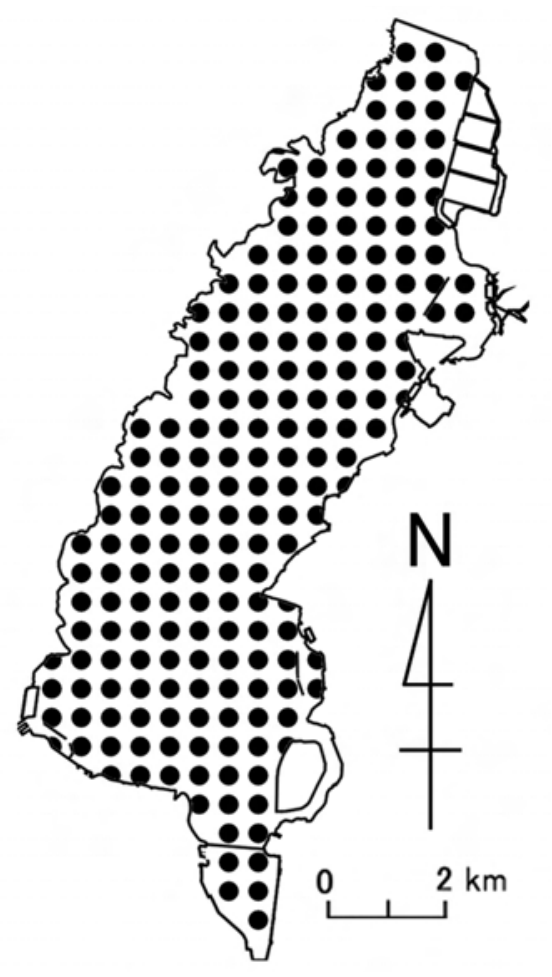

Fig. 1. Points in the southern basin of Lake Biwa that were evaluated for the estimation of potential occurrence of submerged macrophytes. Two hundred points are set on a grid spaced at 500-m intervals.

図 1. 南湖の沈水植物の分布可否の推定を行った地点. 500 $\mathrm{m}$ 間隔のメッシュの格子点上に 200 地点を設定した。

果の比較を行った。

\section{4 年秋の湖底の光環境の特異性の検証}

1994 年の水位低下が沈水植物の分布拡大の契機之 なった可能性の検討は次の要領で行った。まず, 水位低 下によって湖底に届く光が増加したかどうかを検討する ため, 1994 年の $4 \sim 9$ 月の各月について 200 地点の有 光深度を推定し, 水深と比較して分布の可否を判定し, 分布可能な水域の面積を求めた。ここで得られる面積 は, 前項に記した潜在植生水域とは定義が異なる。光環 境の経月変化を見るために, $4 \sim 8$ 月の有光深度の上位 2 番目の值ではなく, 各月の有光深度を用いているから である。従ってここで得られる面積は, 沈水植物の分布 の可能性を基準とした相対的な湖底の光環境の指標であ り, 厳密には沈水植物の分布可能な範囲そのものではな いが，1994 年の水位低下時とほかの時期の湖底の光環 境の比較のために用いる。以下, この手順で得られた水 域の面積を相対潜在植生水域の面積と呼ぶ。

次に, 1994 年の水位低下時の光環境が 1994 年以前の 
年の同じ時期に較べて良かったかどうかを検討するた め，1979～2004 年の 8, 9, 10 月のそれぞれの月につい て相対潜在植生水域の面積を推定し，その経年变化を調 ベた。

\section{過去の沈水植物の分布面積の収集}

$1979 \sim 2004$ 年の南湖の沈水植物の分布面積を既存 の文献から収集し，1979，1983，1984，1994，1995， 1997，2000，2001，2002，2003 年の10 回の值を得た。 このうち，1979年および 1983 年の分布面積は原著の入 手が困難なことから, 水資源開発公団 (1996) の表に拠っ た。他の分布面積の出典は 1984 年：水資源開発公団 (1996)，1994 年および 2000 年 : Hamabata and Kobayashi (2002), 1995 年 : 滋賀県水産試験場 (1998), 2001 年 : 芳賀（2006），2002 年：芳賀ら（2006），2003 年：Haga et al.（2007）である。1997 年の沈水植物の分布範囲の面 積は, 今本ら（2006）の図をスキャナーでコンピューター に取り込み, CANVAS 8（Deneba co. ltd.）で被度を考慮 しない面積として算出した。

\section{結果}

定期観測における透明度の観測地点数の変化と, 水位 の算出法の変更が潜在植生水域の面積予測に与える影響 の検討

方法の項に述べたように，透明度の観測地点数は年に よって変動している。この影響を検討するため, 20 地点, 19 地点, 18 地点の透明度を用いて推定した潜在植生水 域の数を Table 1 に示した。18 地点モデルで推定された 潜在植生水域の数は，1992～ 2004 年の 20 地点モデル に対して -4〜0 地点, $1981 〜 1991$ 年の 19 地点モデル に対して最大で -9〜 1 地点の範囲にあり, 全推定地点 200 点に対する影響は $5 \%$ 未満だった。このため, 20 地 点モデルに代えて 18 地点モデルを用いても, 沈水植物 の潜在的な分布範囲の議論には大きな影響は出ないと判 断し，最も長い期間のデータを利用できる 18 地点モデ ルを採用した。

次に，水位のデータの問題を検討した。国土交通省の データベースから琵琶湖の 5 地点平均水位と鳥居川水位 の両方が取得できる 1992 ～ 1995 年と 2003 ～ 2004 年に ついて，両者の水位を用いた場合の沈水植物が分布可能 な地点数を比較したところ，鳥居川の水位を用いたほう が $1 \sim 5$ 地点多くなる傾向が見られた。従って，鳥居川 の水位を推定に用いる 1991 年以前の沈水植物の分布範
Table 1. Estimated numbers of potential vegetated areas in the southern basin of Lake Biwa, based on three models respectively employing transparency data from 20, 19, or 18 sites; these data from periodic observations by Shiga prefectural government and the Ministry of Land, Infrastructure and Transport of Japan.

Table 1. 滋賀県と国土交通省が実施している定期観測の透 明度のデータを, それぞれ 20 地点, 19 地点, 18 地点用 いる3つのモデルで推定された潜在植生水域の数。

\begin{tabular}{|c|c|c|c|}
\hline \multirow[b]{2}{*}{ Year } & \multicolumn{3}{|c|}{ Number of potential vegetated areas } \\
\hline & 20 -point model & 19-point model & 18-point model \\
\hline 1979 & & & 42 \\
\hline 1980 & & & 71 \\
\hline 1981 & & 132 & 132 \\
\hline 1982 & & 108 & 99 \\
\hline 1983 & & 150 & 147 \\
\hline 1984 & & 174 & 175 \\
\hline 1985 & & 67 & 67 \\
\hline 1986 & & 127 & 124 \\
\hline 1987 & & 118 & 116 \\
\hline 1988 & & 139 & 131 \\
\hline 1989 & & 108 & 108 \\
\hline 1990 & & 99 & 97 \\
\hline 1991 & & 57 & 52 \\
\hline 1992 & 51 & 50 & 51 \\
\hline 1993 & 81 & 82 & 80 \\
\hline 1994 & 138 & 138 & 134 \\
\hline 1995 & 99 & 99 & 99 \\
\hline 1996 & 141 & 141 & 141 \\
\hline 1997 & 145 & 146 & 145 \\
\hline 1998 & 120 & 120 & 117 \\
\hline 1999 & 144 & 144 & 142 \\
\hline 2000 & 166 & 166 & 166 \\
\hline 2001 & 144 & 144 & 144 \\
\hline 2002 & 171 & 171 & 171 \\
\hline 2003 & 187 & 187 & 187 \\
\hline 2004 & 193 & 193 & 193 \\
\hline
\end{tabular}

囲は過大評価の傾向があるが，その影響は小さいと考え られた。

\section{沈水植物の潜在植生水域の面積と実際の分布範囲の面積} の経年変化

18 地点モデルで推定された $1979 \sim 2004$ 年の沈水植 物の潜在植生水域の分布を Fig. 2 亿示した。なお， 200 地点の推定ではメッシュが粗く, 湖岸付近の分布の可否 について誤った情報を与える恐れがあるので，Fig. 2 は 南湖の地図とは重ねずにイメージ図として提示した。南 湖の北部東岸である赤野井湾付近, および湖岸部は対象 期間のほとんどの年で潜在植生水域となった。一方，南 湖の南半分の沖部では，潜在植生水域の分布は年により 大きく変動した。1997 年からは潜在植生水域が明らか 


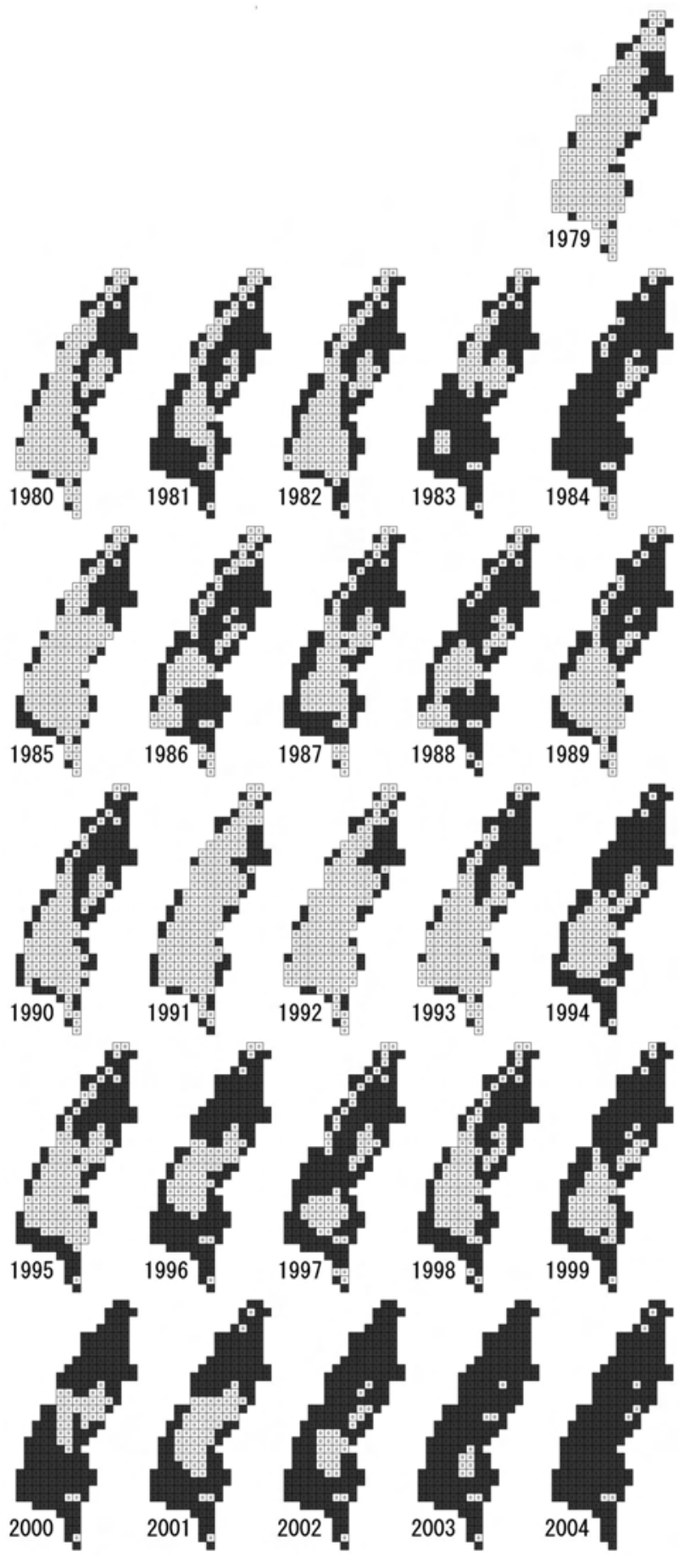

Fig. 2. Changes in the potential vegetated area in the southern basin of Lake Biwa from 1979 to 2004. Shaded area was where submerged macrophytes wee thought to be present.

図 2. 1979-2004 年の南湖における潜在植生水域の分布。グ レーの部分は沈水植物が分布可能な水域を示す。
に増加し，2004 年には南湖のほぼ全域が分布可能と推 定された。

南湖の水面面積を $51.6 \mathrm{~km}^{2}$ ( 芳賀, 2006) として Fig.2 の結果を潜在植生水域の面積に換算し, 同時に過去に 実測された沈水植物の分布面積を示した（Fig. 3）。潜在 植生水域の面積は 1979 年に $11 \mathrm{~km}^{2}$ と最小值を示した後 は拡大傾向が続き, 1984 年には $45 \mathrm{~km}^{2}$ に達した。1985 年に $17 \mathrm{~km}^{2}$ まで縮小したが 1986 年には $32 \mathrm{~km}^{2}$ となり 1988 年の $34 \mathrm{~km}^{2}$ を頂点として再び減少に転じ，1991 年 と 1992 年には $13 \mathrm{~km}^{2}$ となった。1993 年以降は年によっ て増減はあるが拡大傾向が続き, 2004 年には南湖のほ ぼ全域に相当する $50 \mathrm{~km}^{2}$ まで拡大した。実測された沈 水植物の分布面積は, 推定された潜在植生水域の面積よ り常に小さく, 両者の乘離は 1981 ～ 1994 年に顕著だっ た。1995 年以降は両者の乘離が次第に小さくなり 2002 年には分布可能と推定された面積の $98 \%$ に沈水植物の 分布が見られた。

\section{潜在植生水域に対する透明度と水位の影響の検討}

潜在植生水域の面積の大きさを規定する要因として, 透明度と水位のどちらが重要かを調べるため, 有光深度 の算出式から水位の項を削除した数式を用いて潜在植生 水域の推定を行い, その面積を Fig.3 亿黒丸と点線で示 した。水位低下の影響が大きい年には，水位を考慮しな い潜在植生水域の面積（黒丸）は水位を考慮した面積（白 丸）よりも小さくなるが, 期間を通じて白丸より黒丸が 著しく小さい年はなかった（Fig.3）。この結果から潜在 植生水域はほぼ透明度で決定され, 水位の影響は小さい ことが明らかになった。

\section{4 年秋の水位低下が湖底の光環境に与えた影響}

1994 年 $4 \sim 10$ 月の各月について沈水植物の相対潜在 植生水域の面積を求め, 水位の経月変化とともに示した (Fig. 4)。相対潜在植生水域の面積は 6 月に最大となり, 水位が $-1.21 \mathrm{~m}$ まで低下した 9 月の面積はむしろ小さく なった。また, 9 月に分布可能と判定された水域は全て 6 月にも分布可能と判定された。これらの結果は, 1994 年 9 月の水位低下時には湖底の光環境は向上せず, 6 ～ 8 月に比べてむしろ悪化したことを示している。これは 透明度の低下の影響が水位低下の影響を上回ったことが 原因である。

Fig.4の9 月の相対潜在植生水域は, 9 月 6 日に観測 された透明度を用いて推定されている。有光深度の選択 を行わない相対潜在植生水域の推定では, 観測日だけ透 


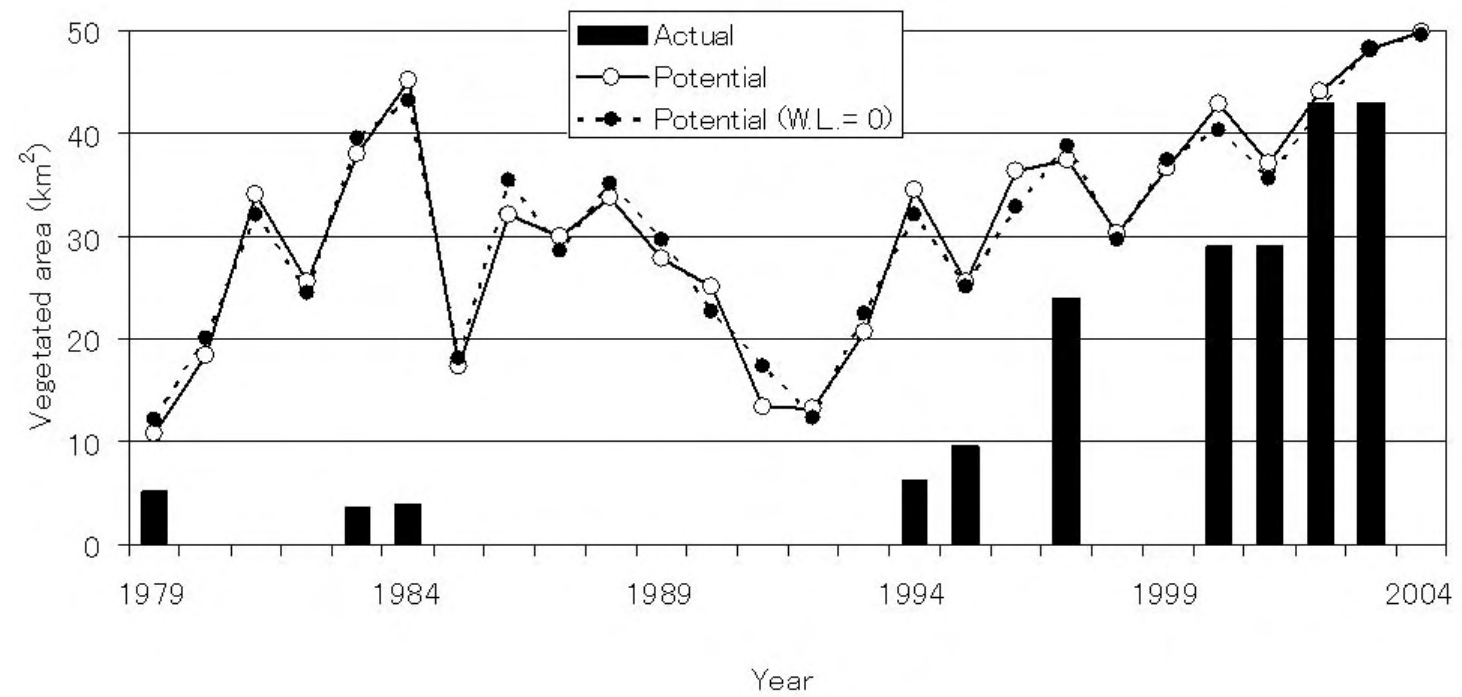

Fig. 3. Annual changes in the potential vegetated area (open circles) and evaluated vegetated area (bars) from 1979 to 2004. Closed circles represent the potential vegetated area assuming a constant water level of $\pm 0 \mathrm{~m}$ on the standard Biwako Surface Level (BSL).

図 3. 1979-2004 年の潜在植生水域の面積の経年変化（○）と実測された分布面積（黒棒）。黒丸は水位を琵琶 湖基準水位 $\pm 0 \mathrm{~m}$ で一定と仮定した場合の潜在植生水域の面積を示す。

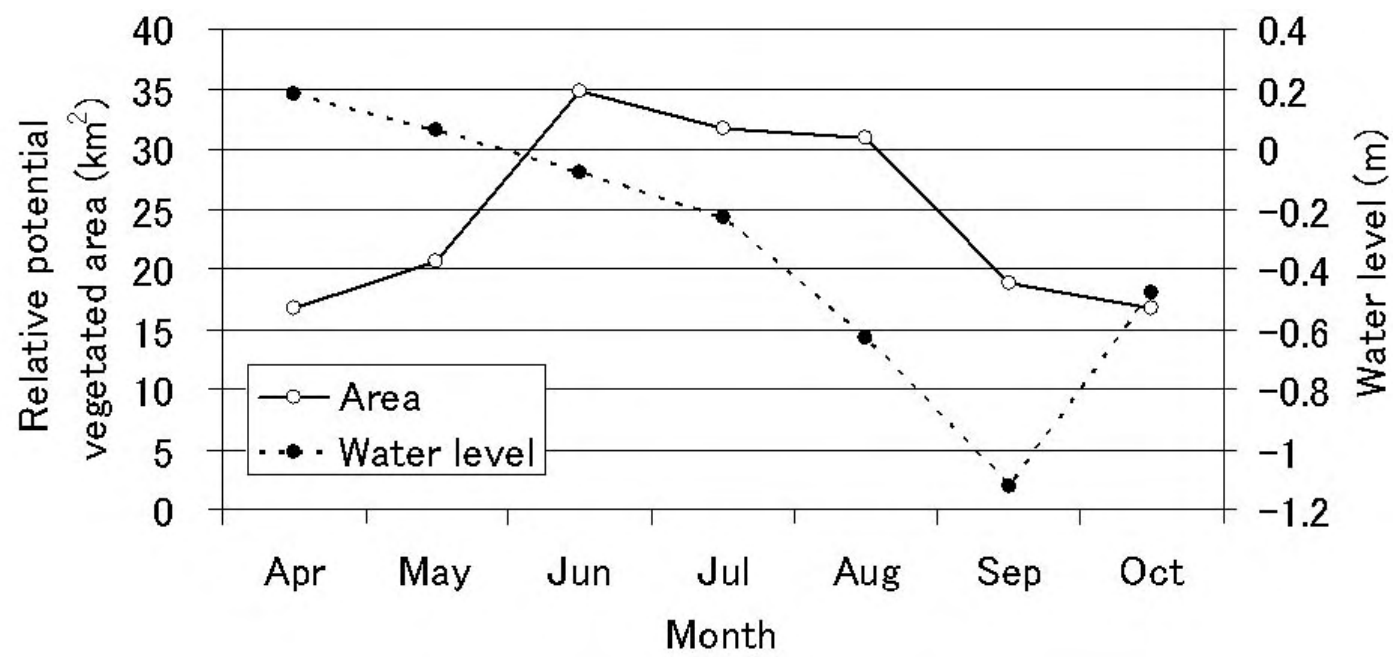

Fig. 4. Monthly fluctuations in the relative potential vegetated area and water level in the southern basin of Lake Biwa from April to October, 1994.

図 4. 1994 年 4 月〜 9 月の相対潜在植生面積と水位の経月変化。

明度が低かった場合には, 面積が過小評価になる。滋賀 県衛生環境センターは 1994 年 9 月 6 日, 13 日, 19 日, 26 日に南湖の 5 地点で透明度の観測を行っている（滋 賀県立衛生環境センター，1996）。そのデータによれば
雄琴沖中央で 9 月 26 日に透明度の上昇が見られるもの の, 他の地点の透明度は 9 月 6 日とほぼ同じかむしろ低 く, このため, 1994 年 9 月の相対潜在植生水域の面積 が過小評価である可能性は小さいと考えられた。 
1994 年 $8 \sim 10$ 月の光環境と, それ以前の年の同じ時 期の光環境の比較

沈水植物の分布拡大の契機としてみた場合, 1994 年 9 月の水位低下は，沈水植物が翌年の繁殖の準備をする時 期に起こった点が重要とされている（浜端，2005）。前 項で 1994 年の中では 9 月は必ずしも光環境が最良では ないとの結果が出たが, 1994 年以前の同じ時期の光環 境よりはよかったかもしれない。そこでこの可能性を検 討した。

1979 年〜 2004 年の $8,9,10$ 月の相対潜在植生水域の 面積の経年変化を Fig.5 に示した。1979〜 1993 年の 15 年間に, 相対潜在植生水域の面積が 1994 年と同等かそ れ以上となった年は， 8 月が 4 回，9月が 8 回，10月が 9 回あり，特に 1986 年や 1988 年は $8 \sim 10$ 月の 3 ケ月 とも 1994 年より相対潜在植生水域の面積が大きくなっ た。これらの結果から, 沈水植物の繁殖において 1994 年は, それ以前の 15 年間と比較して特別に条件の光条 件の良い年ではなかったと考えられた。

\section{考察}

南湖の沈水植物の分布制限要因としての光環境

南湖で沈水植物が分布を拡大した仕組みについては, 1994 年の水位低下が直接的な原因であり，これにより Scheffer et. al. (2001) のカタストロフィックシフトモデ ルにおける turbid state から clear stateへの転換がおこっ た（浜端，2005）というのが唯一の説明であった。しか し, 本研究により, 従来の説明を支持する実証的データ は存在しないことが明らかになった。

まず，水位低下が起こる 1994 年以前の潜在植生水域 が沈水植物の実際の分布範囲より常に大きかった（Figs. 2, 3)。このことは clear state でありながら実際には沈水 植物が分布しなかった場所が広範囲に存在したことを 意味している。つまり 1979～1993 年の南湖は，沈水植 物の分布が湖底の光条件で制限される turbid state ではな かったことになる。

沈水植物が分布拡大に転じた直接的原因と目される 1994 年の水位低下の影響についても，本研究の結果は 否定的だった。水位低下が生じた 9 月の湖底の光条件 は, 同じ年の $6 \sim 8$ 月に較べてむしろ劣悪であり (Fig.4), 1994 年より前の年の同じ時期と較べても特に良好なわ けではなかった（Fig.5）。水位低下により，すでに浅所 に存在していた沈水植物の光条件がよくなり，生産が賦 活化され，翌年以降の分布拡大の契機となった可能性は
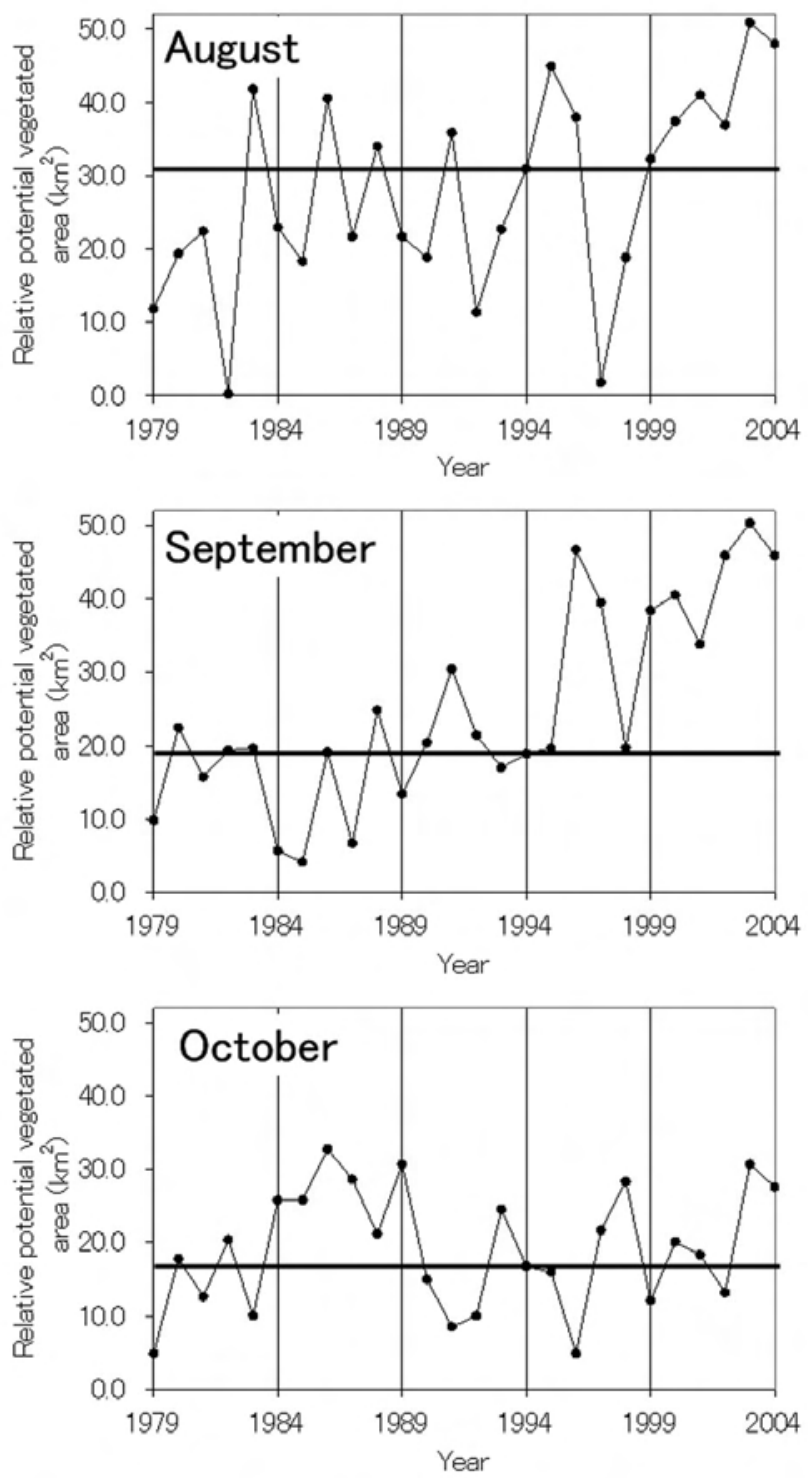

Fig. 5. Annual fluctuations in the relative potential vegetated area in the southern basin of Lake Biwa in August, September, and October of 1979 to 2004. The solid horizontal line represents the area in 1994.

図 5. $1979 \sim 2004$ 年の 8, 9, 10 月の相対潜在植生面積の経 年変化。水平な線は 1994 年の面積を示す。

否定できないが，それだけで沈水植物の分布拡大を説明 することには無理があるだろう。なぜならば, 1994 年 の $8 \sim 10$ 月と同等以上の光環境が実現した年は 1979〜 1993 年の間に複数回あり, そのときは沈水植物の分布 は拡大していないからである。

以上の結果から，1994 年の水位低下を契機とした南 湖の沈水植物の分布拡大を Scheffer et al. (2001)のカタ ストロフィックシフトで説明するのは妥当ではないとい ら結論が得られた。1979〜1993 年の沈水植物の分布が 
光制限だけで説明できないことは, 別の環境要因の存在 を示唆している。この未知の環境要因の候補としては, しゅんせつやシジミ漁による湖底の摚乱，除草剤の影響 などが考光られる（石飛ら，2006）。今後はこれらの項 目に関する研究が必要だろう。

\section{4 年以降の沈水植物の分布拡大と透明度の上昇の関} 係

本研究では, 1994 年以降, 2002 年まで潜在植生水域 が沈水植物の実際の分布面積を上回り続けたことが示さ れた（Figs. 2,3）。この期間は透明度の上昇によって拡 大傾向にあった沈水植物の分布可能域に, 実際の分布が 時間的遅れを持って広がっていったと解することができ る。

浜端（2005）は南湖の透明度が 1994 年以降に上昇傾 向にあること, 特に沈水植物がよく繁茂している南湖南 部でその傾向が著しいことを示し, 沈水植物の分布拡大 が透明度の上昇に寄与した可能性を指摘した。この指摘 はおそらく正しいと思われるが，沈水植物の分布拡大を 透明度上昇の主要因と判断することは留保しなければな らない。Haga et al. (2007) は南湖の沈水植物群落の容積 が南湖の水体に占める容積率（PVI）が 2003 年時点で $23-27 \%$ となり, 局所的にはクロロフィル a 濃度が低 下寸る境界值 30\%（Canfield et al., 1984）を超えたこと を報告した。沈水植物の存在が透明度を低下させる可能 性について数值的な根拠をもって論じられたのはこの報 告が最初であり, PVIがより低いと思われる2003 年以 前の沈水植物の寄与は明らかではない。また, 本研究で は沈水植物の分布拡大が見られなかった 1979〜1984 年 にも 1994 年以降と同程度の潜在植生水域の拡大が見ら れた（Fig. 3）。1994 年以降の透明度の低下原因につい てはまだ詳細な検討が終わっていない。ほかの要因につ いても検討する必要があると思われる。

PVI がクロロフィル濃度を低下させるレベルに達した 2003 年以降は, 沈水植物の存在が透明度を高く維持し, そのことで沈水植物群落が安定して維持される状態にあ ると予想される。2006 年まで沈水植物の分布範囲や群 落容積は減少傾向にはなく (芳賀ら, 未発表), 今後も 南湖では沈水植物が優占する状況が続くだろう。ただし, 1964 年の沈水植物の分布面積の縮小を招いたような工 事による大規模な濁水の発生（生嶋，1966）や，それに 匹敵する別の要因による濁水の発生があれば，南湖の沈 水植物は壊滅的な打撃を受け, 分布が急に縮小寸るかも しれない。

\section{謝辞}

本研究の実施にあたって琵琶湖水位のデー夕提供の便 宜を図っていただいた滋賀県河港課の方々，ならびに英 文作成の際に助言を下さった M.J. Grygier 博士に感謝し ます。

\section{参考文献}

Canfield Jr. D.E., J.V. Shireman, D.E. Colle, W.T. Haller, C.E. Watkins and M.J. Maceina (1984) : Prediction of chlorophyll a concentrations in Florida lakes: Importance of aquatic macrophytes. Canadian Journal of Fisheries and Aquatic Sciences, 41:497-501.

芳賀裕樹 (2006): 琵琶湖南湖の面積について. 陸水学雑 誌， 67:123-126.

芳賀裕樹 - 大塚泰介 - 松田征也 - 芦谷美奈子 (2006): 2002 年夏の琵琶湖南湖における沈水植物の現存量と 種組成の場所による違い。陸水学雑誌，67:69-79.

Haga, H., T. Ohtsuka, M. Matsuda and M. Ashiya (2007): Echosounding observation of coverage, height, PVI, and biomass of submerged macrophytes in the southern-basin of Lake Biwa, Japan. Limnology, 8:95-102.

浜端悦治 (2005): 琵琶湖の沈水植物群落. 滋賀県琵琶湖 研究所報, 22:105-119, 滋賀県, 大津.

Hamabata, E. and Y. Kobayashi (2002): Present status of submerged macrophyte growth in Lake Biwa: Recent recovery following a summer decline in the water level. Lakes \& Reservoirs: Research and Management, 7:331-338. 生嶋功 (1966) : 水草班中間報告 琵琶湖の水生高等植 物. びわ湖生物資源調查団中間報告 (一般調查の 部 ):313-341.

石飛裕・平塚純一 ・山室真澄 (2006): 沈水植物群落の衰 退とその原因. 里湖 モク採り物語 50 年前の水面下の 世界. 平塚純一・山室真澄・石飛裕 (著):104-108. 生 物研究社, 東京.

今本博臣・及川拓治・大村朋広・尾田昌紀・熟谷いず み (2006): 琵琶湖に生息する沈水植物の1997年か ら 2003 年までの 6 年間の変化. 応用生態工学, 8: 121-132.

水資源開発公団 (1996)：琵琶湖湖岸植生調查業務 報 告書 (本編)。水資源開発公団琵琶湖開発総合管理所, 大津.

大塚泰介・桑原泰典・芳賀裕樹 (2004): 琵琶湖南湖にお ける沈水植物群落の分布および現存量一魚群探知機を 
用いた推定一. 陸水学雑誌，65:13-20.

滋賀県環境白書資料編 (1980-2005), 滋賀県. 大津.

滋賀県立衛生環境センター（1996）：平成 6 年度渴水時 琵琶湖水質詳細調査 調査報告書, 滋賀県. 大津.

滋賀県水産試験場（1998）：平成7年度 琵琶湖沿岸帯 調查報告書, 滋賀県. 彦根.

Scheffer, M., S. Carpenter, J. A. Foley, C. Folks, and B. Walker (2001): Catastrophic shifts in ecosystems. Nature, 413: 591-596.

Takamura, N., Y. Kadono, M. Fukushima, M. Nakagawa, and B.O. Kim (2003): Effects of aquatic macrophytes on water quality and phytoplankton communities in shallow lakes. Ecological Research, 18:381-395. 